\title{
2. INTRODUCTION, BACKGROUND, AND SCIENTIFIC OBJECTIVES: ENGINEERING LEG 142 AT THE EAST PACIFIC RISE ${ }^{1}$
}

\author{
Shipboard Engineering and Scientific Parties ${ }^{2}$
}

\section{INTRODUCTION}

The scientific importance of drilling at spreading ridge crests has been recognized since the inception of ocean-floor drilling. Indeed, such drilling is still viewed as a very high priority, with 12 additional drilling legs recommended in the Ocean Drilling Program's (ODP) Long Range Plan. Deep Sea Drilling Project (DSDP) Leg 54 (Rosendahl, Hekinian, et al., 1980) was the first serious attempt to drill at the East Pacific Rise (EPR), but was unsuccessful because of the serious technological shortcomings of unsupported conventional rotary drilling on essentially bare rock. Despite these early problems, the Conference on Scientific Ocean Drilling (COSOD) I, COSOD II, and several thematic panels of ODP (notably the Lithosphere, Tectonics, and Sedimentary and Geochemical Processes Panels) consistently reaffirmed the great scientific importance of understanding the early origin of oceanic crust by drilling near and at the axes of mid-ocean ridges. ODP Legs 106 and 109 (Detrick, Honnorez, Bryan, Juteau, et al., 1988) at the Mid-Atlantic Ridge convincingly showed that new technological capabilities were essential for spudding into bare rock, for establishing/casing a drill hole, and for coring the hole to the desired depth.

The diamond coring system (DCS) was designed and built to overcome some of the initial problems encountered in ridge-crest drilling, especially the problems of poor hole stability and low core recovery. The DCS drills a small-diameter (3.96 in.) hole using narrow-kerf diamond drilling, which has been used to drill successfully in fractured rocks on land. The DCS was tested and modified after the two initial engineering legs, 124E (Harding, Storms, et al., 1990) and 132 (Storms, Natland, et al., 1991). Leg 142 was meant not only to continue testing and development, but also to provide the first scientific results from drilling at the EPR. Leg 142 was thus the first leg of a multi-leg drilling program at the EPR, conceived by the East Pacific Rise Working Group (EPRWG) and the East Pacific Rise Detailed Planning Group (EPRDPG) and described in their reports to the Lithosphere Panel and Planning Committee.

The EPRDPG listed five scientific objectives of fundamental importance to understanding the origin of young ocean crust. These objectives address the questions of (1) the structure and composition of "zero-age" crust, (2) fluid-rock interaction above a shallow magma chamber, (3) fluid flow and mineralization, (4) temporal variation of lava chemistry erupted at the ridge axis, (5) and crustal calibration for geophysical remote-sensing studies, such as seismic reflection, refraction, tomography, and others. Further, the EPRDPG recommended several sites in the general area of the EPR at $9^{\circ} 30^{\prime} \mathrm{N}$ to implement a strategy of segment-scale drilling. Initially, Leg 142 was planned to focus on a site $1 \mathrm{~km}$ west of the EPR axis (Site EPR-1). However, on the basis of site survey work discussed later, the primary site for Leg 142 was changed to Site EPR-2 (drilled as Site 864), exactly at the axis.

The purpose of this chapter is to provide a brief review of previous work at Site 864 and its surroundings, as well as an overview of the

\footnotetext{
${ }^{1}$ Storms, M.A., Batiza, R., et al., 1993. Proc. ODP, Init. Repts., 142: College Station, TX (Ocean Drilling Program).

${ }^{2}$ Shipboard engineering and scientific parties are as given in the list of participants preceding the contents.
}

scientific results of the leg. Unfortunately, technical problems with secondary heave compensation for the DCS prevented recovery of abundant core. These problems, as well as some of the technical successes achieved during this engineering leg, are discussed in other chapters of this volume. Despite problems with the DCS, samples of basalt from two holes (Holes 864A and 864B) were recovered in drill bits, core barrels, and junk baskets. These samples are the first subsurface samples recovered from the EPR, and thus are of great interest.

\section{PREVIOUS STUDIES}

The EPR in the vicinity of $9^{\circ} 30^{\prime} \mathrm{N}$ is an exceptionally well-studied portion of the global ridge system. The purpose of this section is not to give a comprehensive review of the existing data, but rather to briefly mention the studies that have been done in the context of drilling at Site 864. Drilling during Leg 142 resulted in the spudding of Holes $864 \mathrm{~A}, 864 \mathrm{~B}$, and $864 \mathrm{C}$. The first two are cased to 13.3 and $7.1 \mathrm{~m}$ and Holes $864 \mathrm{~A}$ and $864 \mathrm{C}$ have hard-rock guide bases (HRB), so that they can be reoccupied in the future and deepened. Alternatively, the guide bases could be picked up and moved to another site (e.g., EPR-1) if desired.

\section{GENERAL GEOLOGY}

The general tectonic framework of the EPR in the region of Site 864 is discussed by Klitgord and Mammerickx (1982). Carbotte and Macdonald (1992) discuss the general tectonic setting of the EPR from $8^{\circ} \mathrm{N}$ to $10^{\circ} 30^{\prime} \mathrm{N}$ (Fig. 1). Site 864 is located at a depth of $2581 \mathrm{~m}$ on the axis of the East Pacific Rise at $9^{\circ} 30.85^{\prime} \mathrm{N}, 104^{\circ} 14.66^{\prime} \mathrm{W}$. The site is near the mid-point of a second-order ridge segment bounded to the north at $10^{\circ} 10^{\prime} \mathrm{N}$ by the Clipperton transform fault, and to the south at $9^{\circ} 03^{\prime} \mathrm{N}$ by an overlapping spreading center (OSC; Macdonald et al., 1984; Fig. 1). The full spreading rate along this segment is approximately $11 \mathrm{~cm} / \mathrm{yr}$ (Klitgord and Mammerickx, 1982). The width of the ridge crest tapers southward, from a maximum of $4 \mathrm{~km}$ near the Clipperton transform fault to only $2 \mathrm{~km}$ at the $9^{\circ} 03^{\prime} \mathrm{N}$ OSC. This southward narrowing of the ridge is accompanied by a general increase in axial depth, from less than $2550 \mathrm{~m}$ on top of an axial high at $9^{\circ} 50^{\prime} \mathrm{N}$ to $2760 \mathrm{~m}$ at the $9^{\circ} 03^{\prime} \mathrm{N}$ OSC. From $9^{\circ} 51.5^{\prime} \mathrm{N}$ to $9^{\circ} 26.1^{\prime} \mathrm{N}$, the ridge axis is marked by a narrow trough, less than $200 \mathrm{~m}$ wide and 5-15 m deep (Fornari et al., 1990; Haymon, Fornari, Edwards, et al., 1991). This feature is called an "axial summit caldera" (ASC) by Haymon, Fornari, Edwards, et al. (1991) because it has apparently formed primarily from volcanic collapse along the ridge axis following magma drain-back.

Between the Clipperton transform fault and the OSC at $9^{\circ} 03^{\prime} \mathrm{N}$, small bends, offsets, and discontinuities of the ASC and the ridge axis partition the ridge crest into 11 fourth-order segments, $5-15 \mathrm{~km}$ in length (Langmuir et al., 1986; Haymon, Fornari, Edwards, et al., 1991; Fig. 2). These en-echelon segments consistently step right along the EPR axial zone south of $9^{\circ} 54^{\prime} \mathrm{N}$. Near-bottom images and submersible observations confirm that the youngest lavas in the area are present along segment B (Fig. 2), on the axial high at $9^{\circ} 45^{\prime} \mathrm{N}-51.5^{\prime} \mathrm{N}$. In April 1991, divers in the Alvin submersible observed evidence of an active eruption in the ASC along this segment (Haymon, Fornari, Von Damm, Lilley, et al., 1991; Haymon, Fornari, Von Damm, Edmond, 


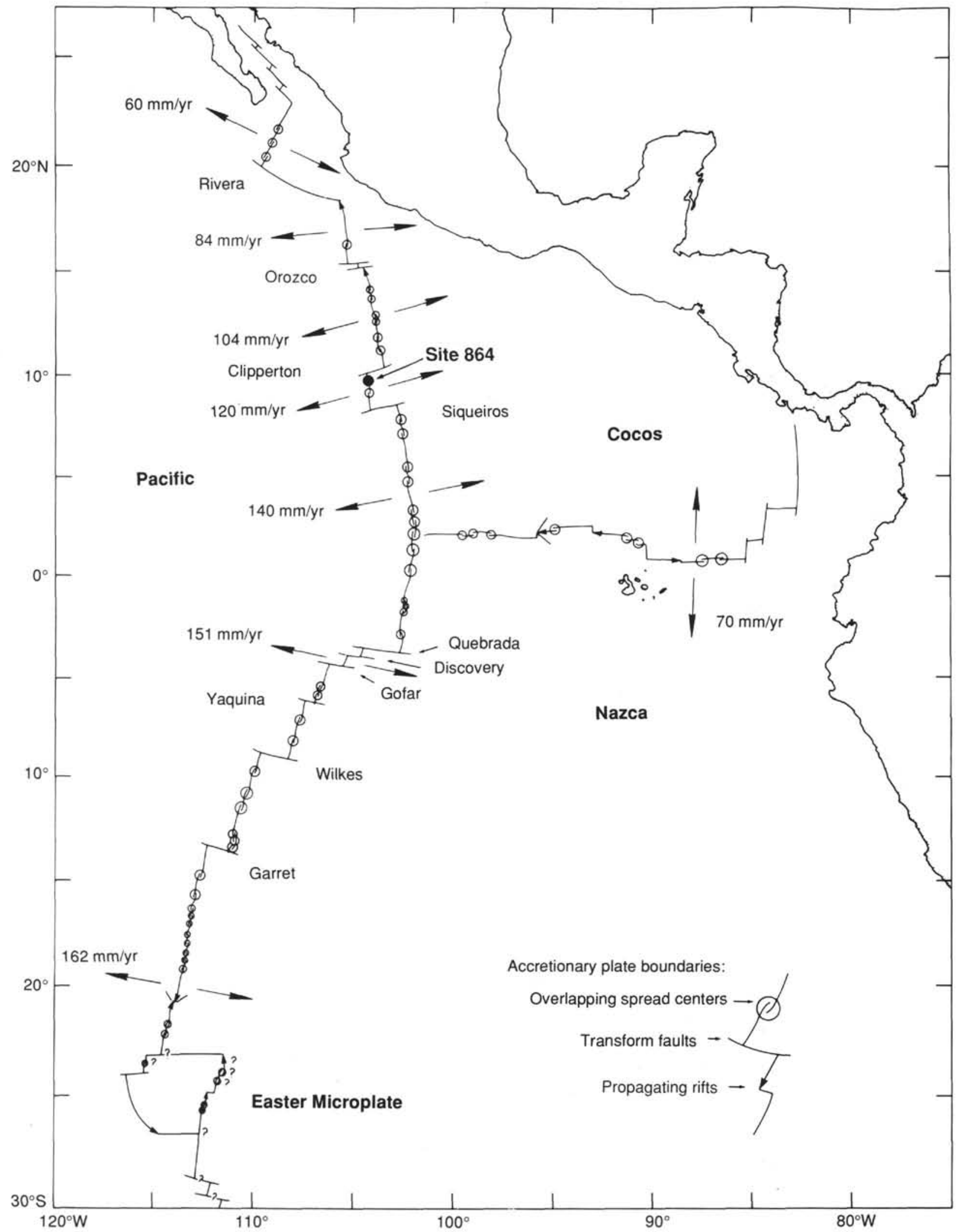

Figure 1. Location map (from Carbotte and Macdonald, 1992) of the Site 864 region. 


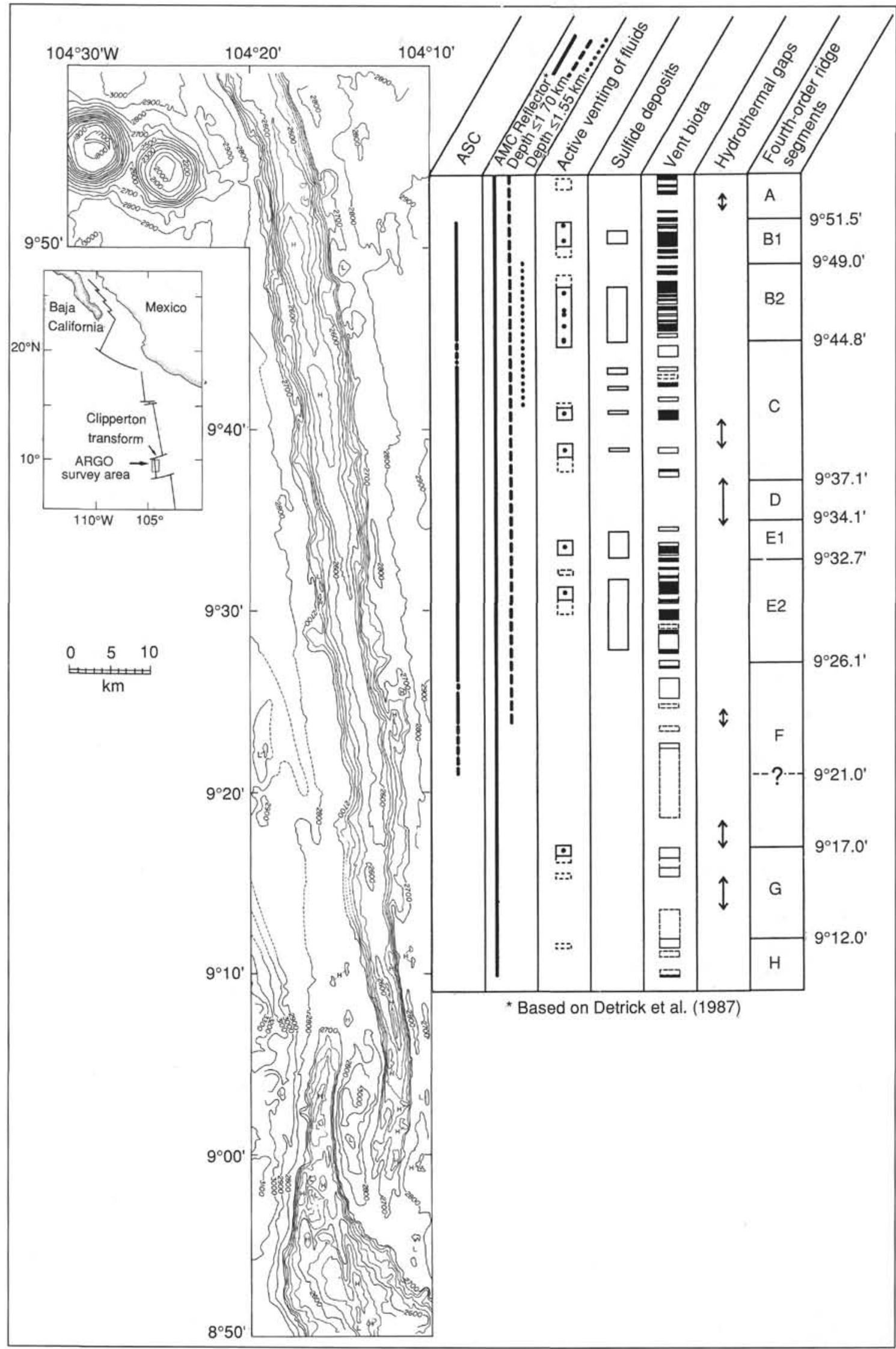

Figure 2. Bathymetry, segmentation, and hydrothermal venting phenomena at the East Pacific Rise in the vicinity of Site 864 (from Haymon, Fornari, Edwards, et al., 1991). 
1991). On successive fourth-order segments southward from the eruption area, the relative ages of axial lavas increase systematically (Haymon, Fornari, Edwards, et al., 1991; Wright and Haymon, 1991), except in the area from $9^{\circ} 21^{\prime} \mathrm{N}$ to $9^{\circ} 12^{\prime} \mathrm{N}$, where older lavas are partially to completely buried by fresh flows. South of this area, the age of lavas along the axial zone continues to increase to the tip of the OSC (Sempere and Macdonald, 1986).

The variations observed along-strike in age of axial lavas and depth to the ridge axis (both increasing away from the axial high at $9^{\circ} 50^{\prime} \mathrm{N}$ ) are spatially correlated with along-strike variations in the compositions of axial lavas and the distribution of hydrothermal vents and deposits. Detailed petrologic study of dredged rock samples collected at $\approx 1.8-\mathrm{km}$ intervals along the ridge axis has shown that the axial basalts of this ridge segment are normal depleted mid-ocean ridge basalt (N-MORB) derived from a single parent magma (Batiza and Niu, 1992). These lavas exhibit a general increase in degree of fractionation southward from the axial high at $9^{\circ} 50^{\prime} \mathrm{N}$ to the $9^{\circ} 03^{\prime} \mathrm{N}$ OSC (Batiza and Niu, 1992). Many hydrothermal vents and mineral deposits were mapped in the ASC along this ridge segment and are known collectively as the Venture Hydrothermal Fields (Haymon, Fornari, Edwards, et al., 1991; Figs. 2 and 3). The hottest and most abundant active vents are found on segment B, between $9^{\circ} 45^{\prime} \mathrm{N}$ and $9^{\circ} 51.5^{\prime} \mathrm{N}$, a segment that was actively erupting in March-April 1941 (although eruptions had stopped by March 1991; K. Von Damm, pers. comm., 1992). The number of active vents decreases, and the number of extinct mineral deposits increases, on successively older fourthorder segments southward from the eruption area to the southern limit of the ASC at $\approx 9^{\circ} 26^{\prime} \mathrm{N}$ (Haymon, Fornari, Edwards, et al., 1991). Except for sparse occurrences of galatheid crabs and hydrothermal staining of basalt, little evidence of past or present vent activity is found on the older axial lavas south of $9^{\circ} 26^{\prime} \mathrm{N}$. Nevertheless, one additional active smoker, located at $9^{\circ} 16.8^{\prime} \mathrm{N}$, is associated with the area of fresh lava flows at $9^{\circ} 21^{\prime}-12^{\prime} \mathrm{N}$.

A robust seismic reflector thought to be the top of an axial magma chamber is present beneath the ridge axis between the Clipperton transform and $\approx 9^{\circ} 09^{\prime} \mathrm{N}$ (Detrick et al., 1987; Fig. 3). The reflector is detected at $\approx 1.5 \mathrm{~km}$ beneath the seafloor at $9^{\circ} 45^{\prime}-50^{\prime} \mathrm{N}$, where active eruptions were observed in April 1991. It deepens southward to a depth of $\approx 1.7 \mathrm{~km}$ beneath Hole $864 \mathrm{~A}$ and drops off sharply south of $9^{\circ} 28^{\prime} \mathrm{N}$ to $\approx 2.0 \mathrm{~km}$. Seismic data indicate that this apparent deepening of the magma chamber reflector south of $9^{\circ} 28^{\prime} \mathrm{N}$ may be due to a westward shift in the axis of the magma chamber with respect to the topographic ridge axis (Mutter et al., 1988; Toomey et al., 1990). For the Clipperton- $9^{\circ} \mathrm{N}$ segment as a whole, the apparent southward increase in the depth of the magma-chamber reflector along strike has been interpreted to be genetically linked with the observed southward increase in degree of magma fractionation (Batiza and Niu, 1992) and decrease in hydrothermal venting (Haymon, Fornari, Edwards, et al., 1991).

\section{GEOLOGY OF SITE 864}

Three ODP site surveys were conducted in 1989-1991 to gather detailed information about the EPR segment south of Clipperton and to establish the local geology in the vicinity of Site 864: (1) a nearbottom optical/acoustic study of the axial zone from $9^{\circ} 09^{\prime} \mathrm{N}$ to $9^{\circ} 54^{\prime} \mathrm{N}$ using the ARGO camera/sonar sled (Haymon, Fornari, Edwards, et al., 1991; Fornari et al., 1990); (2) a near-bottom seismic refraction experiment (the NERO experiment; Purdy et al., 1991; Christeson et al., 1992); and, (3) an Alvin submersible dive program (the Adventure Program; Haymon, Fornari, Von Damm, Lilley, et al., 1991; Haymon, Fornari, Von Damm, Edmond, 1991).

Site 864 is located on segment E2 (Fig. 2), approximately $25 \mathrm{~km}$ south of the area of recent eruption on segment B (Fig. 4). Segment E is bounded to the north by a right-stepping offset of the ASC at $\approx 9^{\circ} 35^{\prime} \mathrm{N}$, and to the south by the termination of the ASC at $\approx 9^{\circ} 26^{\prime} \mathrm{N}$. A small bend in the ASC at $9^{\circ} 32.7^{\prime} \mathrm{N}$ divides segment $\mathrm{E}$ into two

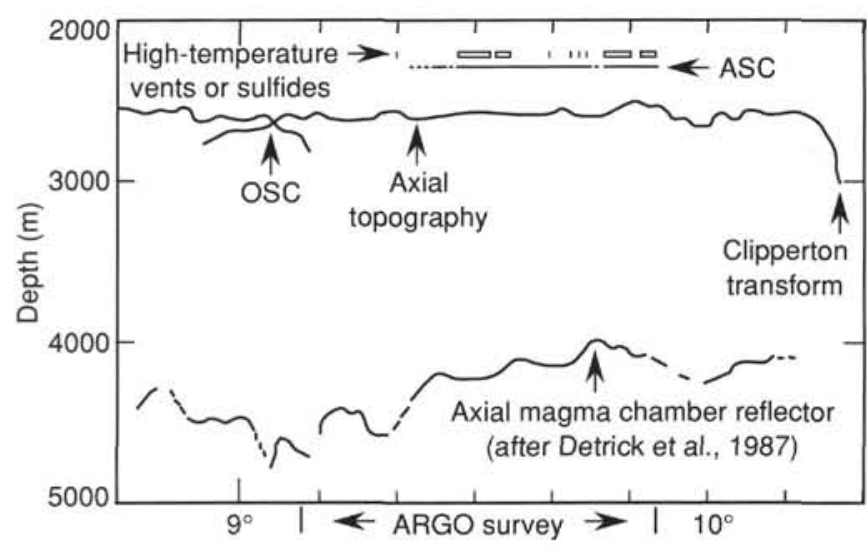

Figure 3. Along-axis bathymetry, depth to the axial magma chamber, and hydrothermal vent locations at the EPR near Site 864 (from Haymon, Fornari, Edwards, et al., 1991).

subsegments, E1 (north of the jog) and E2 (south of the jog). The strike of the ASC along subsegment E2 is $355^{\circ}$.

At $9^{\circ} 30.8^{\prime}-31^{\prime} \mathrm{N}$, the ASC and the seafloor out to 100-200 m away were imaged with ARGO and surveyed on four submersible dives (Haymon and Fornari, unpubl. data; see Fig. 5). The width of the ASC across the top is $\approx 200 \mathrm{~m}$ (Fig. 6), and the depth is $8-11 \mathrm{~m}$. Outside the ASC, to a distance of at least $100-200 \mathrm{~m}$ from the rim, are sedimented lobate flows pocked with shallow collapse pits 1-2 m deep and 2-3 m across (Fig. 6). Inside the ASC is an extensive deposit of collapse rubble consisting of platey pieces $5-20 \mathrm{~cm}$ thick. These are remnant pieces of lobate crusts that were the frozen roofs of lava ponds. When magma drained out from underneath, the lobate crusts collapsed into a chaotic jumble of polygonal plates, or, where the crust was thicker $(20-40 \mathrm{~cm})$, into a cracked pavement of larger pieces similar in appearance to a buckled concrete slab. The rim of the ASC is a ragged lip that has formed from roof collapse. Overhangs are present where uncollapsed, pillar-supported roof remnants extend out from the rim over caverns in the ASC walls. The depth of the ASC rim is $2571 \mathrm{~m}$ and the walls bounding the ASC are 5-9 $\mathrm{m}$ high. Their $60^{\circ}-90^{\circ}$ slopes are covered with collapse rubble interspersed with lava pillars and uncollapsed, lobate-topped roof remnants. The west wall is $\approx 60 \mathrm{~m}$ wide adjacent to Site 864 , while the east wall is $\approx 90 \mathrm{~m}$ wide (Fig. 6). This asymmetry is due to the presence of benches 3-20 $\mathrm{m}$ wide on the east wall at depths of 2574 and $2577 \mathrm{~m}$.

The central floor of the ASC lies at a depth of 2581-2583 m. It is flooded by a distinctive flat-to-ropey massive basalt flow (dubbed the "ODP Flow") that is $\approx 3.5 \mathrm{~m}$ thick and $60 \mathrm{~m}$ wide at the drill site. The glassy, sediment-dusted flow is younger than the lobate lavas outside the ASC. The ODP Flow extends for at least $260 \mathrm{~m}$ alongstrike and varies in width from 20 to $80 \mathrm{~m}$. Flow striations are oriented subparallel to the strike of the ASC. Submersible observations of contact relationships indicate that the ODP Flow traveled along-strike and ponded within a pre-existing linear collapse or depression along the west margin of the ASC. The ODP Flow does not appear to have spilled out of the containing depression, suggesting that the eruption was a small one issuing from a fracture now buried beneath the flow. Fissures and cooling cracks in the flow are up to several meters wide, and may have vertical offsets of up to $1 \mathrm{~m}$ near the margin of the flow. Spacing between cracks is spatially variable, from $2-5 \mathrm{~m}$ up to $8-15 \mathrm{~m}$.

In a $1500 \mathrm{~m}^{2}$ area approximately $50-100 \mathrm{~m}$ north of Hole $864 \mathrm{~A}$, diffuse venting of low-temperature $\left(11^{\circ}-14^{\circ} \mathrm{C}\right)$ hydrothermal fluid from fissures in the ODP Flow supports a community of mussels, clams, and crabs. Extinct sulfide edifices up to $10 \mathrm{~m}$ high are found within $200 \mathrm{~m}$ north and south of the drill site. The nearest active high 


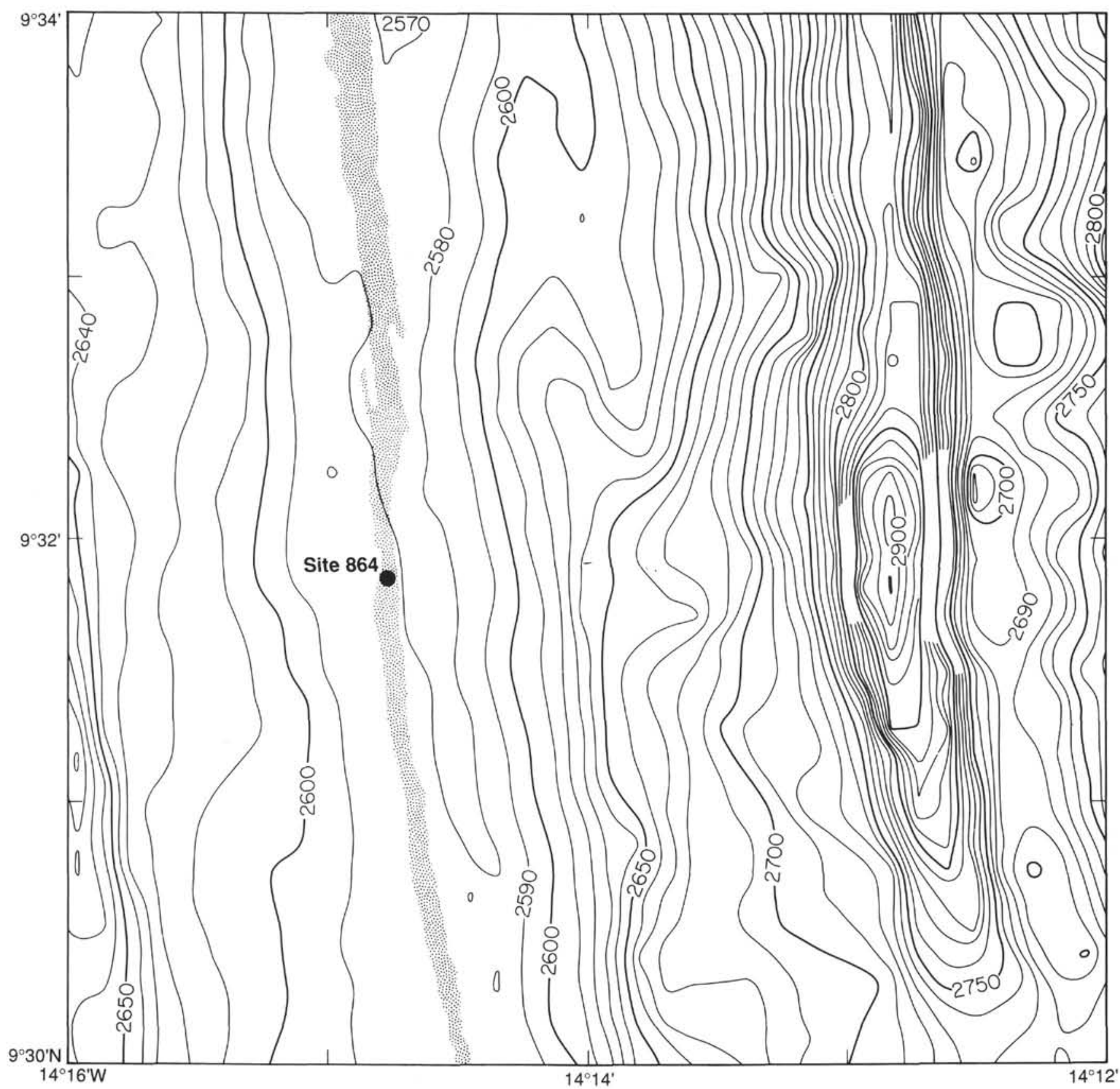

Figure 4. Bathymetry (in meters) of the area of Site 864, showing the boundaries of the ASC.

temperature vents are located in the ASC $\approx 700 \mathrm{~m}$ north of Site 864 . These active hot vents are barely flowing and appear to be dying. The closest vigorous black smoker is located on segment E1 at $9^{\circ} 33.5^{\prime} \mathrm{N}$. Abundant inactive edifices mapped with ARGO are strung out along the ASC south to $9^{\circ} 27^{\prime} \mathrm{N}$. Haymon, Fornari, Edwards, et al. (1991) propose that the hydrothermal system on segment $\mathrm{E}$ is in a late stage of evolution and is dying from south to north.

Two passive markers were left on the ODP Flow: Marker \#1 at a site where the fissure density was low and the flow surface very flat $\left(9^{\circ} 30.85^{\prime} \mathrm{N}, 104^{\circ} 14.66^{\prime} \mathrm{W}\right.$; Fig. 6), and Marker $\# 2$ in the area of diffuse hydrothermal venting and vent biota $\left(9^{\circ} 30.89^{\prime} \mathrm{N}, 104^{\circ} 14.69^{\prime} \mathrm{W}\right)$. Marker \#1 was located during Leg 142 using the video camera on the drill string, and Hole $864 \mathrm{~A}$ is sited approximately 20 m northwest of the marker (Fig. 6).

\section{SEISMIC STUDIES}

One of the primary reasons for interest in scientific ODP drilling at the East Pacific Rise was the identification from multichannel seismics of a coherent reflector marking the top of an axial magma chamber (Herron et al., 1980; Detrick et al., 1987; Mutter et al., 1988). Beneath the axis of the EPR crest, the top of the magma chamber is $1.7 \mathrm{~km}$ below the seafloor at the drill site (Vera et al., 1990) but this apparent depth to the magma chamber lessens to the west. In threedimensional mapping of the seismic structure of the EPR crest, Toomey et al. (1990) found that the magma chamber reaches its shallowest depth of about $1 \mathrm{~km}$ below seafloor about $1 \mathrm{~km}$ to the west of the rise axis, beneath crust that is 20,000 years old. This depth and offset from the axis are right at the limits of resolution of the 


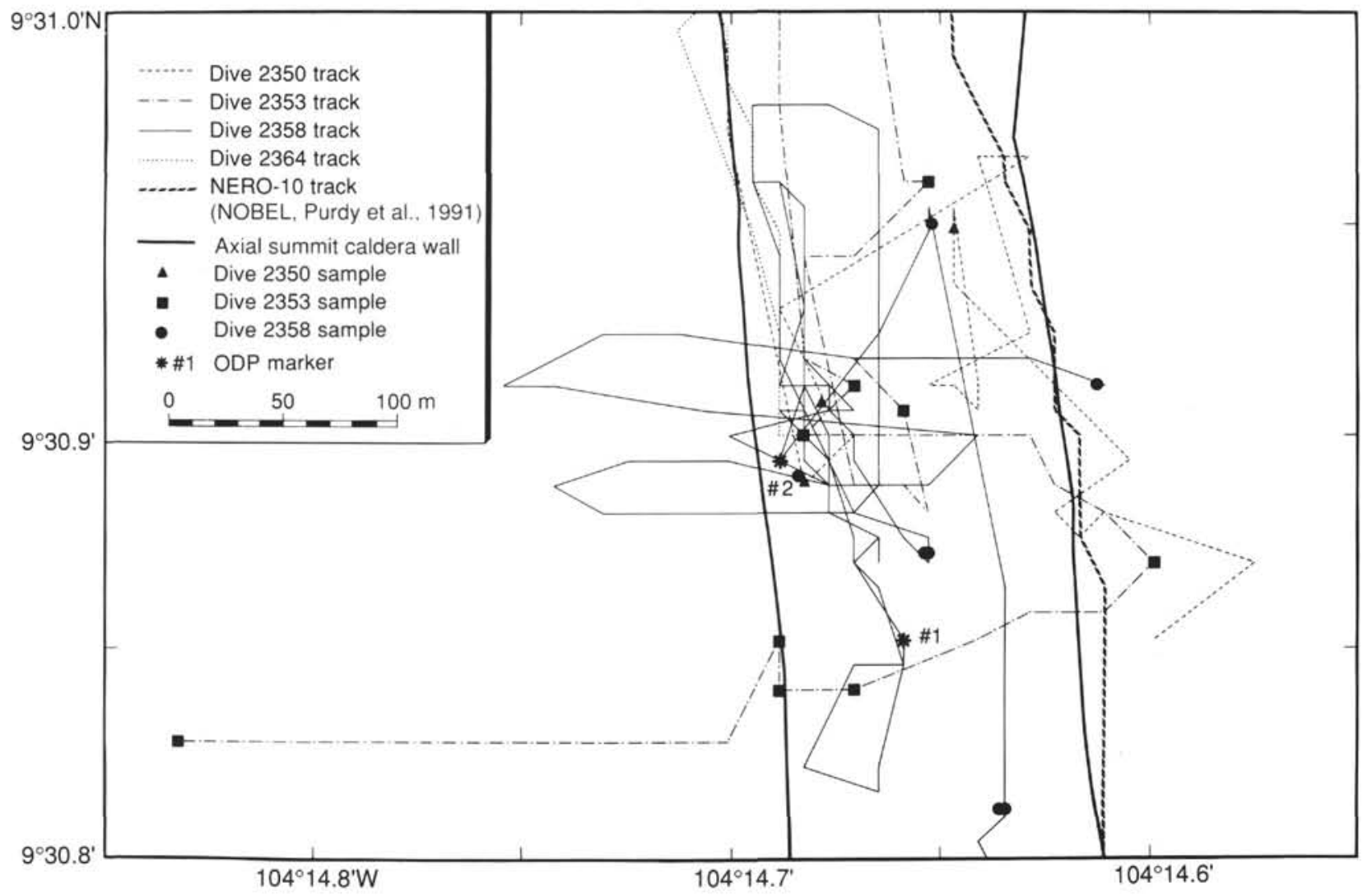

Figure 5. Alvin dive tracks at the EPR near Site 864, forming the basis of the map in Figure 6 .

tomographic inversion used by Toomey et al. (1990), but it is clear that a magma chamber reaching to within $1.5 \mathrm{~km}$ of the seafloor exists under the near-western flank of the rise. Such a shallow magma chamber is an intriguing target for drilling; it was hoped that experiments in bare-rock drilling on the East Pacific Rise crest would lead to the establishment of drill holes that might eventually be reentered in order to recover rock from the roof of the magma chamber itself. Two potential sites were chosen: EPR-1 above the shallowest point of the magma chamber, as determined by Toomey et al. (1990), and EPR-2 (Site 864) within the axial summit caldera. The axial lowvelocity zone is $3-4 \mathrm{~km}$ wide (Detrick et al., 1987) and could be reached from either EPR-1 or EPR-2.

In order to measure the detailed shallow structure of the proposed drill sites, Purdy et al. (1991) conducted seismic refraction experiments using the deep-towed explosive source NOBEL and oceanbottom hydrophones. The experimental results are reported in detail by Christeson et al. (1992). By using shots within a few meters of the ocean bottom, this experiment avoided the geometry of traditional seismic experiments in which little energy (and hence little information) is returned from the shallowest seafloor. Purdy et al. (1991) made seismic measurements along ridge-parallel refraction lines at each of the proposed drill sites, and at several other sites to make up a cross-ridge transect at $9^{\circ} 30^{\prime} \mathrm{N}$ (Fig. 7). They also made measurements within the ASC at $9^{\circ} 33^{\prime}$ and at $12^{\circ} 50^{\prime} \mathrm{N}$. Their results from the vicinity of $9^{\circ} 30^{\prime} \mathrm{N}$ are summarized in Figure 8 . The structure of the axial summit caldera and the flanks differ markedly (Christeson et al., 1992). A thin $(<100 \mathrm{~m})$, slow $(2-2.5 \mathrm{~km} / \mathrm{s})$ layer forms the top of zero-age crust and this is underlain by a faster layer with velocities of $5.3 \mathrm{~km} / \mathrm{s}$ at a depth of 200 meters below seafloor (mbsf). On the flanks, the surficial low-velocity layer is significantly thicker (130$180 \mathrm{~m})$ and faster $(2.4-3.2 \mathrm{~km} / \mathrm{s})$. This is underlain by a layer with velocities ranging from 4.2 to $4.7 \mathrm{~km} / \mathrm{s}$ (Fig. 8).
Christeson et al. (1992) interpret the low-velocity surface layer to be fractured and brecciated basalt. The slight increase in velocity from axis to flank is probably the result of a difference in morphology: the ASC lavas are predominantly sheet and lobate flows, while the flanks have pillows erupted over lobated flows (Alvin submersible observations by R. Batiza and others during February and March, 1992, on dives 2489 and 2491). More difficult to explain is the apparent decrease in velocity of the material beneath the low-velocity layer in going from the axis to the flanks. Christeson et al. (1992) suggest that the material of greater than $5 \mathrm{~km} / \mathrm{s}$ on the zero-age lines is dikes (only $120 \mathrm{mbsf}$ at $9^{\circ} 30^{\prime} \mathrm{N}$ ), deepening rapidly with age as more lavasoverflows from the axis-bury them to form the thick $(250+\mathrm{m})$ sequence of material below $4.2 \mathrm{~km} / \mathrm{s}$ on the flanks. Alternatively, the $5 \mathrm{~km} / \mathrm{s}$ velocity material at the axis might be massive, low-porosity flows, which are fractured tectonically to yield the lower velocity material of the flanks. Drilling could help to distinguish between these possibilities. From the bottom refraction experiments, the thinnest surficial low-velocity layer is at site EPR-2 within the ASC (the zero-age line labeled $9^{\circ} 30^{\prime} \mathrm{N}$ in Fig. 8). There the thickness is only $50 \mathrm{~m}$. Everywhere else the layer is thicker. In particular, at EPR-1, the original primary choice for an EPR site, the layer is over $100 \mathrm{~m}$ thick and underlain by a transition to higher velocity material (line $20 \mathrm{~W}$ in Fig. 8). The implication is that the basalt is heavily fractured to about $150 \mathrm{mbsf}$. Because of the difficulty in drilling through thick sequences of fractured rock, the primary location for drilling was switched to EPR-2 (Purdy et al., 1991), which became Site 864.

\section{PETROLOGIC STUDIES}

Langmuir et al. (1986) described samples dredged from the EPR between $8^{\circ} \mathrm{N}$ and $15^{\circ} \mathrm{N}$. A detailed study of the axis in the area of the seismic tomography experiment (the area of Site 864) was conducted 
by Batiza and Niu (1992) using dredges spaced about every $1.8 \mathrm{~km}$ along the axis. Additional samples on the axis and on the flanks of the EPR were collected by Perfit et al. (1991a, 1991b). So far, these studies show that the axial lavas are primarily depleted N-MORB with rare, more enriched E-MORB occurring at some fourth-order discontinuities along axis and at other places on the flanks, off axis. Batiza and Niu (1992) showed that there is a correlation between axial depth and chemistry between $9^{\circ} 17^{\prime} \mathrm{N}$ and $\approx 9^{\circ} 50^{\prime} \mathrm{N}$, with shallow areas of the axis having more primitive lavas (higher $\mathrm{MgO}$ contents and $\mathrm{MgO} / \mathrm{FeO}$ ) and deeper areas having more fractionated lavas (Fig. 9). Furthermore, since there is a correlation between axial depth and depth of the seismic magma chamber, there is also a correlation between the chemistry of axial lavas and axial magma chamber (AMC) depth. Chemical differences among the samples of N-MORB can all be explained by crystal fractionation involving a single parental melt. Batiza and Niu (1992) invoked a magma chamber that has compositional zoning along axis (Fig. 10) to explain the observed along-axis chemical variation in the vicinity of Site 864 .

\section{REFERENCES*}

Batiza, R., and Niu, Y., 1992. Petrology and magma chamber processes at the East Pacific Rise $\approx 9^{\circ} 30^{\prime}$ N. J. Geophys. Res., 97:6779-6798.

Carbotte, S., and Macdonald, K.C., 1992. East Pacific Rise $8^{\circ}-10^{\circ} 30^{\prime} \mathrm{N}$ : evolution of ridge segments and discontinuities from SeaMARC II and three-dimensional magnetic studies. J. Geophys. Res., 97:6959-6982.

Christeson, G.L., Purdy, G.M., and Fryer, G.J., 1992. Structure of young upper crust at the East Pacific Rise near 9 ${ }^{\circ} 30^{\prime}$ N. Geophys. Res. Lett., 19:1045-1048.

Detrick, R., Honnorez, J., Bryan, W.B., Juteau, T., et al., 1988. Proc. ODP, Init. Repts., 106/109: College Station, TX (Ocean Drilling Program).

Detrick, R.S., Buhl, P., Vera, E., Mutter, J.C., Orcutt, J., Madsen, J., and Brocher, T., 1987. Multi-channel seismic imaging of a crustal magma chamber along the East Pacific Rise. Nature, 326:35-41.

Fornari, D.J., Haymon, R.M., Edwards, M., and Macdonald, K.C., 1990. Volcanic and tectonic characteristics of the East Pacific Rise Crest $9^{\circ} 09^{\prime} \mathrm{N}$ to $9^{\circ} 54^{\prime} \mathrm{N}$ : implications for fine-scale segmentation of the plate boundary. Eos, 71:625.

Harding, B.W., Storms, M.A., et al., 1990. Proc. ODP, Init. Repts., 124E: College Station, TX (Ocean Drilling Program).

Haymon, R.M., Fornari, D., Von Damm, K., Edmond, J., Lilley, M., Perfit, M., Shanks, III, W.C., Grebmeier, J., Lutz, R., Carbotte, S., Wright, D., Smith, M., McLaughlin, E., Beedle, N., Seewald, J., Reudelhuber, D., Olson, E., and Johnson, F., 1991. East Pacific Rise erupts north of Leg 142 drillsite! JOI-USSAC Newsl., 4:4-12

Haymon, R.M., Fornari, D.J., Edwards, M.H., Carbotte, S., Wright, D., and Macdonald, K.C. 1991. Hydrothermal vent distribution along the East Pacific Rise crest $\left(9^{\circ} 09^{\prime}-54^{\prime} \mathrm{N}\right)$ and its relationship to magmatic and tectonic processes on fast-spreading mid-ocean ridges. Earth Planet. Sci. Lett., 104:513-534.

Haymon, R.M., Fornari, D.J., Von Damm, K.L., Lilley, M., Edmond, J., Perfit, M., Shanks, W.C., III, Lutz, R., Grebmeier, J., Seewald, J., Carbotte, S., Wright, D.,
Smith, M., McLaughlin, E., Olson, E., Reudelhuber, D., Johnson, F., 1991. Active eruption seen on East Pacific Rise. Eos, 72:505-507.

Herron, T.J., Stoffa, P.L., and Buhl, P., 1980. Magma chamber and mantle reflections-East Pacific Rise. Geophys. Res. Lett., 7:989-992.

Klitgord, K.D., and Mammerickx, J., 1982. Northern East Pacific Rise: magnetic anomaly and bathymetric framework. J. Geophys. Res., 87:6725-6750.

Langmuir, C.H., Bender, J.F., and Batiza, R., 1986. Petrologic and tectonic segmentation of the East Pacific Rise. $5^{\circ} 30^{\prime} \mathrm{N}-14^{\circ} 30^{\prime} \mathrm{N}$. Nature, 322:422-429.

Macdonald, K.C., Sempere, J.-C., and Fox, P.J., 1984. East Pacific Rise from Siqueiros to Orozco fracture zones: along-strike continuity of axial neovolcanic zone and structure and evolution of overlapping spreading centers. J. Geophys. Res., 89:6049-6069.

Mutter, J.C., Barth, G.A., Buhl, P., Detrick, R., Orcutt, J.A., and Harding, A.J. 1988. Magma distribution across ridge-axis discontinuities on the East Pacific Rise from multichannel seismic images. Nature, 336:156-158.

Perfit, M.R., Fornari, D.J., Smith, M., Langmuir, C., Bender, J., and Haymon, R.M., 1991a. Fine-scale petrological variations along the East Pacific Rise crest $9^{\circ} 17^{\prime} \mathrm{N}$ to $9^{\circ} 54^{\prime} \mathrm{N}$ : results from ALVIN diving and rock coring during the Adventure Program. Eos, 72:491.

, 1991b. Geochemical mapping using a grid of lava samples around the proposed ODP bare-rock drillsite near $9^{\circ} 31^{\prime} \mathrm{N}$ : spatial and temporal variability on the crest of a fast-spreading MOR. Eos, 72:495-496.

Purdy, G.M., Christeson, G.L., Fryer, G.J., and Berge, P.A., 1991. Upper crustal structure of the East Pacific Rise from ocean bottom refraction experiments: interpretation and placement of a deep drill hole, Eos, Suppl.: Spring Meeting Program and Abstr., 72:262. (Abstract)

Rosendahl, B.R., Hekinian, R., 1980. Init. Repts. DSDP, 54: Washington (U.S. Govt. Printing Office).

Sempere, J.-C., and Macdonald, K.C., 1986. Deep-Tow studies of the overlapping spreading centers at $9^{\circ} 03^{\prime} \mathrm{N}$ on the East Pacific Rise. Tectonics, 5:881-900.

Storms, M.A., Natland, J.H., et al., 1991. Proc. ODP, Init. Repts., 132: College Station, TX (Ocean Drilling Program).

Toomey, D.R., Purdy, G.M., Solomon, S.C., and Wilcock, S.D., 1990. The three-dimensional seismic velocity structure of the East Pacific Rise near latitude $9^{\circ} 30^{\prime} \mathrm{N}$. Nature, 347:639-645.

Vera, E.E., Mutter, J.C., Buhl, P., Orcutt, J.A., Harding, A.J., Kappus, M.E., Detrick, R.S., and Brocher, T.M., 1990. The structure of 0- to 0.2-m.y.-old oceanic crust at $9^{\circ} \mathrm{N}$ on the East Pacific Rise from expanded spread profiles. J. Geophys. Res., 95:15529-15556.

Wright, D.J., and Haymon, R.M., 1991. Abundance and distribution of fissures and age distribution of lavas along the axial zone of the East Pacific Rise $\left(9^{\circ} 12^{\prime}-54^{\prime} \mathrm{N}\right)$ : manipulation of ARGO data using the Geographic Information System ARC/INFO. Eos, 72:495.

* Abbreviations for names of organizations and publication titles in ODP reference lists follow the style given in Chemical Abstracts Service Source Index (published by American Chemical Society).

\section{Ms 142IR-102}




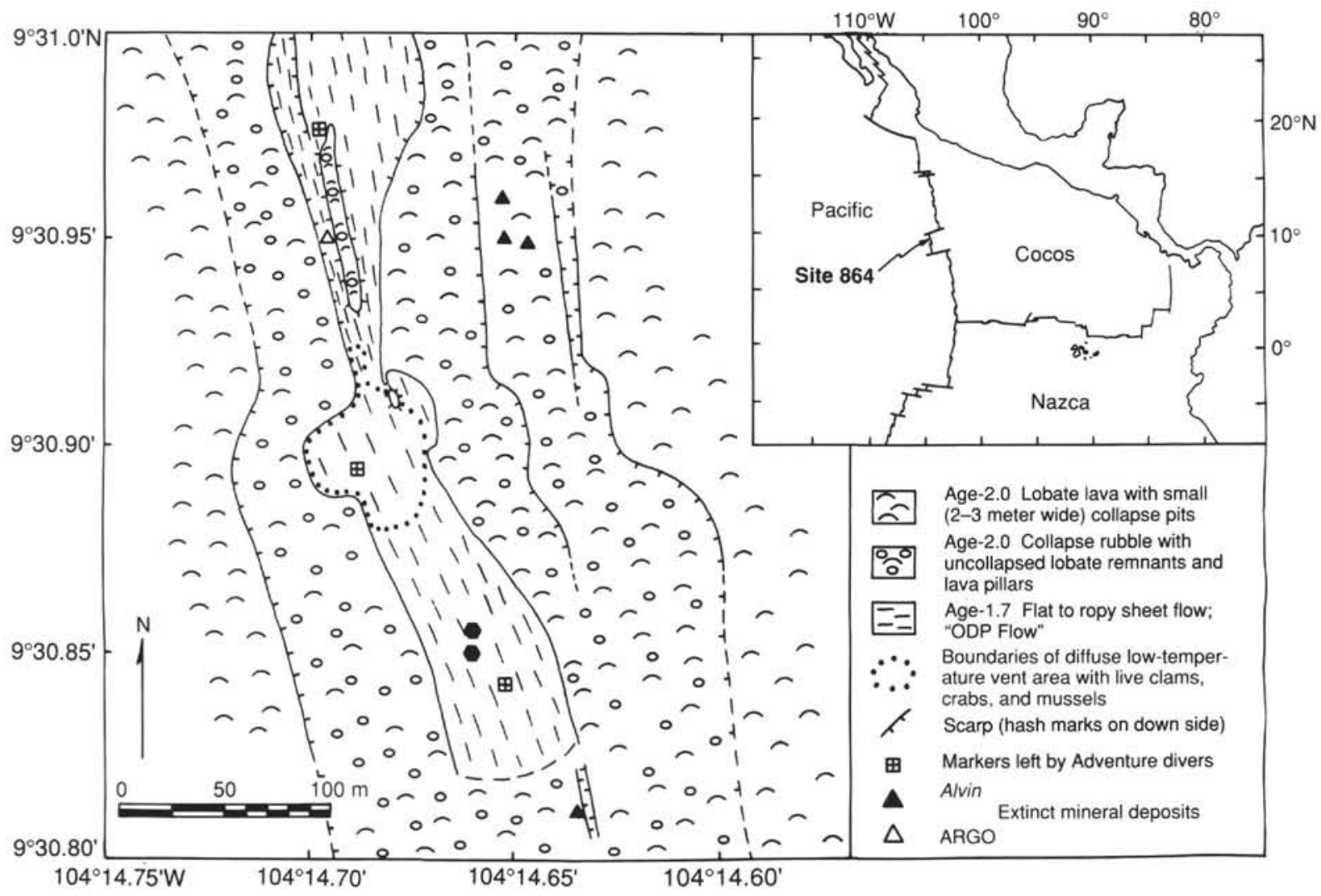

Figure 6. Location and geologic map of Site 864 and vicinity. The hard-rock guide bases for Holes 864A and 864B are shown by the solid hexagons; the southern hexagon represents Hole 864A. 


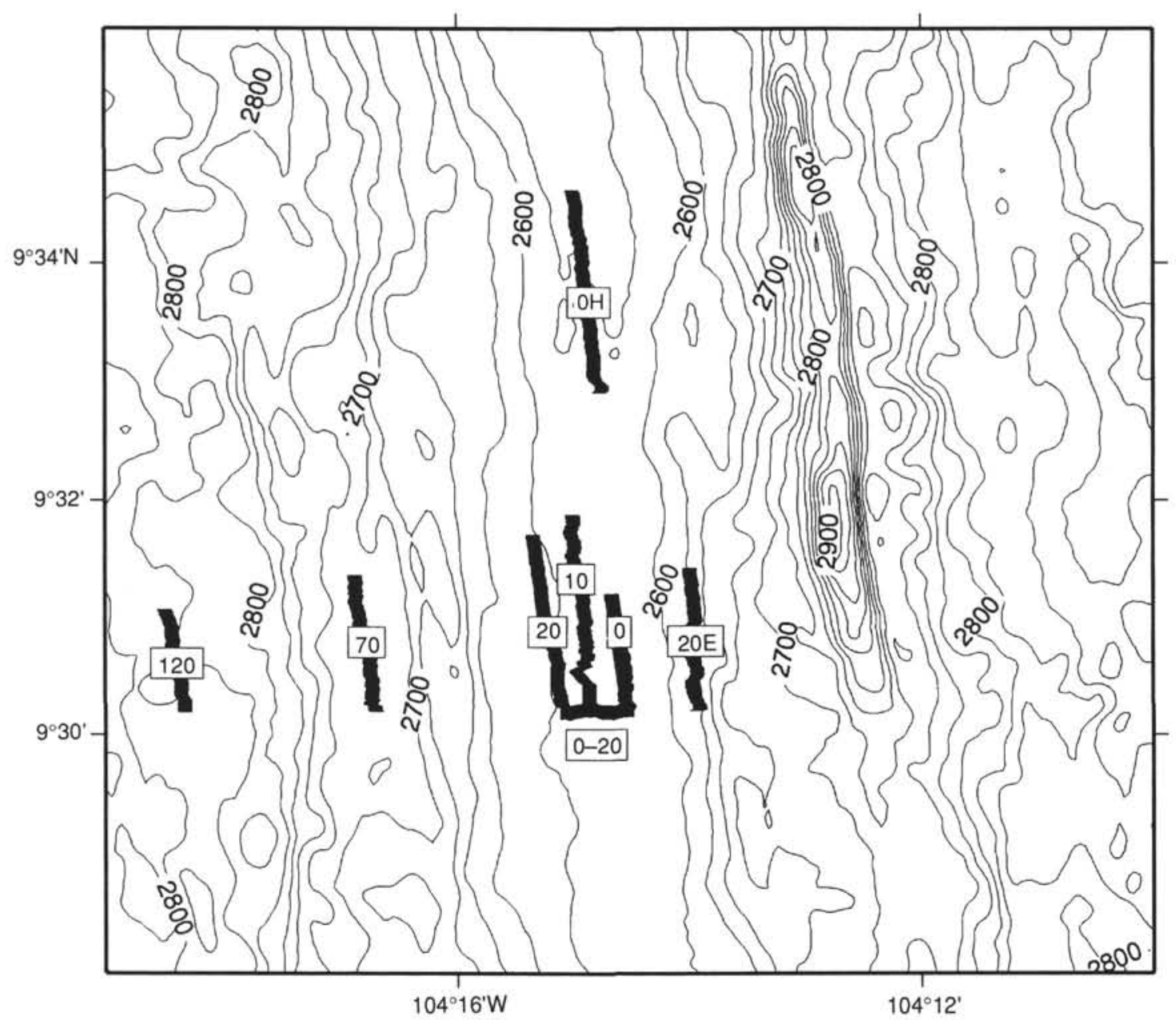

Figure 7. SeaBeam bathymetry (in meters) and locations of on-bottom seismic refraction lines in the vicinity of the EPR at $9^{\circ} 30^{\prime} \mathrm{N}$ (Christeson et al., 1992). Shot lines for the refraction experiments are the heavy black lines; each is labeled with the approximate age in kiloyears. Line 0 samples the Site 864 structure. 


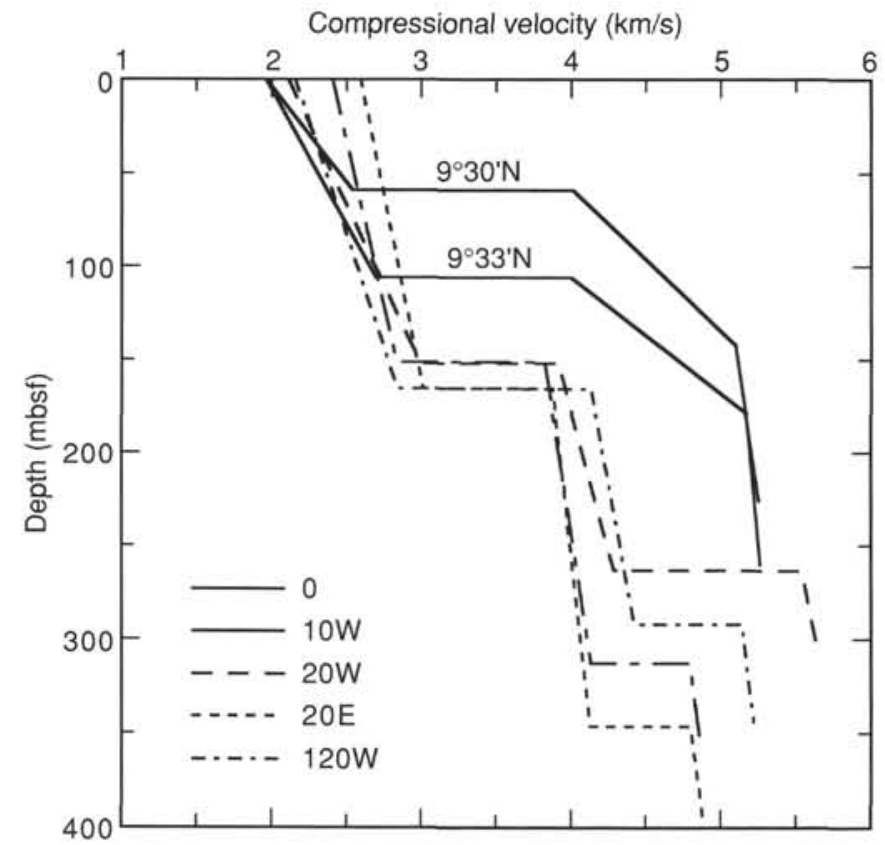

Figure 8. Velocity profiles measured in on-bottom refraction experiments by Christeson et al. (1992). Axial structure (solid lines) differs substantially from flank structure (dotted). The numbers on the flank profile labels are the approximate ages in kiloyears. Two axial lines were shot, at $9^{\circ} 30^{\prime} \mathrm{N}$ and $9^{\circ} 33^{\prime} \mathrm{N}$. Flank lines were all shot to the west of the axis except line $20 \mathrm{~W}$. There is no systematic age dependence apparent in the flank data.

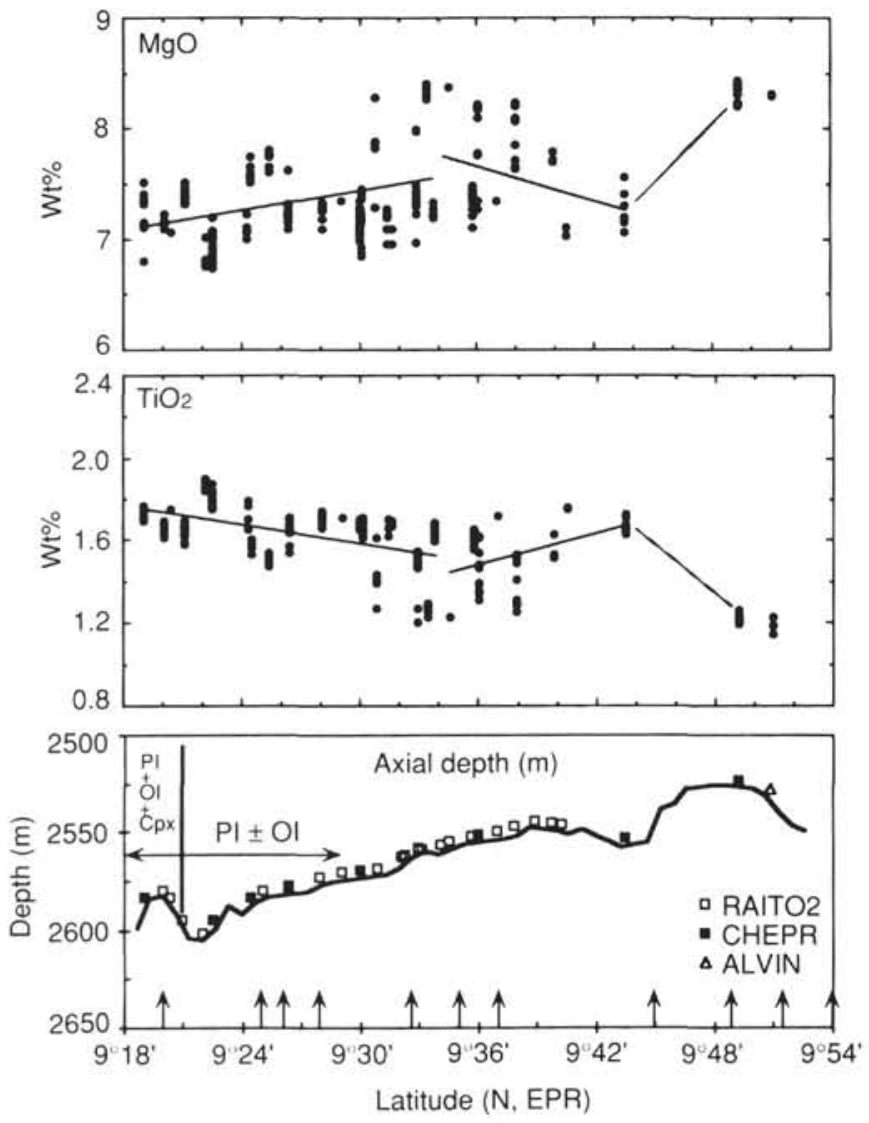

Figure 9. Along-axis chemical variation of lavas at the EPR near Site 864 (from Batiza and Niu, 1992). $\mathrm{PI}=$ plagioclase; $\mathrm{Ol}=$ olivine; $\mathrm{Cpx}=$ clinopyroxene. Samples collected by dredging (RAITO2 and CHEPR) and Alvin dive (ALVIN),

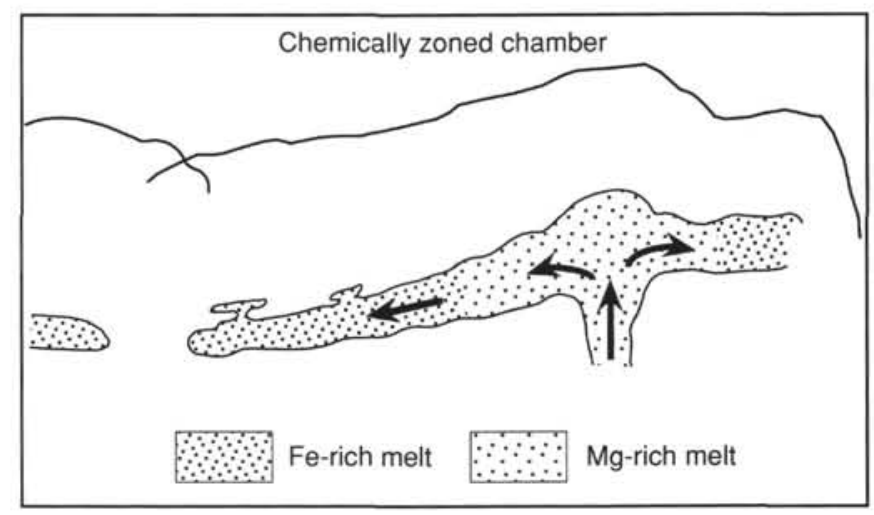

Figure 10. Magma chamber model of Batiza and Niu (1992). 